\title{
Chapter \\ [9] \\ Indigenous knowledge in forest conservation, species diversity and stocking potential: A historical perspectives of northwest Tanzania
}

\author{
Gisandu K. Malunguja1 ${ }^{1,}$, Ratan Chowdhury ${ }^{2}$, \\ Setho Mokhets'engoane ${ }^{3}$, Nadarajah Pravin Diliban ${ }^{4}$, \\ Tamrat Yimenu Zeleke ${ }^{5}$, Phurailatpam Surjit Sharma ${ }^{6}$, \\ Ashalata Devi ${ }^{6}$ and Chrispinus D.K. Rubanza ${ }^{7}$
}

\begin{abstract}
${ }^{1}$ Department of Technical Education, College of Sciences, Mbeya University of Science \& Technology, 131 Mbeya, Tanzania ${ }^{2}$ Department of Botany, Rangapara College, Rangapara, 784505, Assam, India ${ }^{3}$ Department of Education Foundation, Faculty of Education, National University of Lesotho, Roma 180, Maseru, Lesotho ${ }^{4}$ Department of Biosystems Technology, Faculty of Technology, Eastern University, Sri Lanka ${ }^{5}$ Department of Chemistry, College of Natural and Computational Science, Wachemo University, 667 Hossana, Ethiopia ${ }^{6}$ Department of Environmental Science, School of Sciences, Tezpur University, 784028, Assam, India

${ }^{7}$ Department of Biology, College of Natural and Mathematical Sciences, the University of Dodoma, 259, Dodoma, Tanzania
\end{abstract}

\begin{abstract}
The study evaluated the current status (i.e., species diversity, regeneration, and productivity) of the community forests conserved under indigenous knowledge known as Ngitili of northwest Tanzania. We conducted a field study in 10 community forests using phytosociological approaches. Quantitative data were statistically analyzed using ANOVA, while the differences between mean was checked by LSD at $\mathrm{p}<0.05$ using SPSS software. Results indicated that, out of 10 surveyed community forests, 4 were highly threatened (40\%), 5 were highly disturbed (51\%), while 1 ( $9 \%$ ) was converted to other land use. A total of 66 plant species belonging to 54 genera and 27 families were recorded. Biomass production varied significantly between plants ( $p<0.001)$. Lack of environmental education and anthropogenic activities pose a great challenge among community forests. Therefore, appropriate management interventions are highly required to rectify the situation for the sustainability of these forests.
\end{abstract}

Keywords

Biodiversity, Deforestation, Traditional Ngitili, Kishapu-Tanzania

D. Gisandu K. Malunguja, Email: gmalunguja77@gmail.com (*Corresponding author)

(C) 2021 | Agro Environ Media I Agriculture and Environmental Science Academy, Haridwar, India 


\section{Introduction}

The use of indigenous and traditional knowledge in forest conservation and management among communities, particularly the northwest regions of Tanzania, has been practicing even before the colonial era (Malcolm, 1953; Dery et al., 1999; Barrow and Mlenge, 2003). Some pastoralist communities, such as the Sukuma, the largest ethnic group in northwest Tanzania, set aside and retaining an area of standing vegetation from the beginning of the rainy season and opening it up for grazing at the peak of the dry season (Selemani et al., 2012; Cazzolla-Gatti et al., 2014). Other communities practicing vegetation conservation systems include the Himba (Namibia) and the Borana (Ethiopia), and Masai (Kenya) (Selemani et al., 2012; Duguma et al., 2013). The community forest and vegetation conservation system in the northwest of Tanzania is locally known as "Ngitili" (Malcolm, 1953; Dery et al., 1999; UNDP, 2012). It is one of the local and traditional vegetation conservation systems among the agro-pastoral ethnic group in the Shinyanga region of Tanzania (Otsyina et al., 2008; Buckingham and Hanson, 2015). The system existed as early as even before the colonial era (Duguma et al., 2019). The indigenous knowledge aims to carter acute fodder shortage by providing a good time for vegetation recovery (Barrow and Mlenge, 2003; Treue et al., 2014). Apart from its prominent roles, Ngitili contributes to improving a given environment's ecological conditions (Jama and Zeila, 2005). The system contributes more to species diversity and ecosystem services in the region, such as climate change mitigation through enhanced carbon sequestration (Duguma et al., 2019). It also provides a fundamental source of fuelwood, thatch grass, water catchment, scenic beauty, and diversification of nutrition options (e.g., fruits, vegetables, mushroom, edible insects, wild meat, medication) (Monela et al., 2005; Barrow, 2014; Chirwa, 2014). Apart from forest-based ecosystem services, the system improves households' economies that supplement agriculture income (Zahabu, 2008; Duguma et al., 2013).

Therefore, Ngitili is considered an essential traditional strategy for forestry management, rehabilitation, and restoration in Tanzania. The recognition and incorporation of Ngitili in forest management came into existence in the early 1980s. The government revised its forest policy, emphasizing community participation in forestry management (Zahabu et al., 2009; Treue et al., 2014). It was subsequently reinforced in the Forest Act No.14 of 2002 (URT, 2002). Following the recognition of Ngitili as a traditional vegetation conservation system by the government in the 1980s. The sizes and number of Ngitili increased spontaneously from 600 to 18,607 ha from 1986 to the 1990s (UNDP, 2012). From 250,000 to about 500,000 ha in 2001-2004 (Monela et al., 2005; Buckingham and Hanson, 2015). The system received international recognition as a means of restoring degraded lands and its contribution to forestry restoration, environmental conservation, and atmospheric carbon stocking (Monela et al., 2005; Barrow, 2016; Osei et al., 2018).

\section{Historical perspective about Ngitili and conservation}

Shinyanga region was initially being dominated by dense woodland and bushland with different tree 
species of the genus Acacia, Brachystegia, Jubernardia, Albizia, Commiphora, and Dalbergia (Monela et al., 2005; Otsyina et al., 2008; UNDP, 2012). Other common plants were Grewia, Balanites, Pterocarpus, and Afzelia (Kamwenda, 2002). Dominant tree species were; Acacia tanganyikensis, Acacia polyacantha, Afzilia quanzensis, Brachystegia species, Commiphora africana, Combretum zayeri, and Dalbrgia melanoxylon (Kamwenda, 2002; Barrow, 2014). The forested woodlands provided fodder for livestock and basic needs such as food and fuel for the agro-pastoralists ethnic group in the region. Despite that, the dense forest was also a reservoir for the tsetse flies, transmitting a parasitic disease known as trypanosomiasis to both humans and livestock (Barrow and Mlenge, 2003; Duguma et al., 2019). Therefore, in the 1920s, the colonial authorities instituted a program through which local people were paid to cut down large woodland areas to eradicate the tsetse flies. The Sukuma people were happy with the order, not only for eradicating tsetse flies but also for opening up new grazing and agricultural land (Selemani et al., 2012; Buckingham and Hanson, 2015). Apart from the tsetse flies eradicating program of 1925 to 1960s, other programs that accelerated massive deforestation and land degradation includes; the villagization program of the 1970s (Barrow, 2016) and expansion of cotton production for foreign markets (Otsyina et al., 1992; Selemani et al., 2012; Barrow, 2014). These programs created severe threats to existing forests and ecosystems-based resources (Barrow, 2016). Further, these programs also abandoned the previous traditional practices, including Ngitili, and brought about threats to the ecological system. With the extreme land degradation and deforestation, the region was badly turned into treeless. The late President Nyerere was shocked by what he observed during his visit to the area in 1984. He thereby declared the area as "The Desert of Tanzania" (UNDP, 2012; Barrow, 2016). In response to this calamity, in 1986, the government initiated the land rehabilitation project called the Shinyanga Soil Conservation Programme, better known by its "Swahili acronym HASHI (Hifadhi Ardhi Shinyanga), (UNDP, 2012). The primary function is to promote sound land-use technologies' adoption through awareness-raising with tree planting from hand-outs of exotic tree species seedlings from central nurseries on severely degraded land (Selemani et al., 2012; Barrow, 2016). This approach failed because of the harsh weather, termite attack, low acceptance by the community, and poor management (UNDP, 2012).

Observing the failure in the establishment of the HASHI program in the region, project members made a self-reflection and reformation to involve the community (UNDP, 2012) by making people feel that they are responsible for both destruction and restoration of the landscape (Barrow et al., 2002; Minja and Machanya, 2010). Adopting local and traditional knowledge as one of the strategies for forest restoration was thought and taken in place (Otsyina et al., 2008; UNDP, 2012). Thus, the revival and use of indigenous knowledge, attitudes, and practices, such as Ngitili, based on indigenous knowledge, were given more priority and became more applicable (Akida and Blomley, 2006; Burgess et al., 2010). Local communities were encouraged to participate in forest management by setting aside forest areas to be sustainably managed. Thus, different environmental policies were associated with the system. For instance, Tanzania introduced so-called participatory forest management (PFM), joint forest management (JFM), and Wildlife Management program (URT, 2006; Zahabu et al., 2009; Treue et al., 2014). Other related laws and policies such as; the Village Land Act of 1999 and Land Act of 1999, Tanzania Wildlife Policy of 1998 (Akida and Blomley, 2006), the National Environmental Policy of 1997, 
the Environmental Management Act of 2004, Forest Act 2002, and its regulations of 2004 (URT, 2006) were also enacted. All of these policies and regulations promoted participatory forest resource conservation and management for sustainable use.

Furthermore, the government recognized the decentralization of power to the local community and the traditional guard (Kamwenda, 2002; Monela et al., 2005; Duguma et al., 2013). The Council of Elders, locally known as "Dagashida," is involved in decision-making to ensure sustainable use of the resources and the welfare of the people in Ngitili (Monela et al., 2005). At the same time, the traditional guard (police) locally known as Sungusungu were given power and became the implementers of the by-laws and protecting the communities against invaders. Heavy fines (e.g., a live cow or 40,000 Tanzanian shillings, approximately to 20 USD) were paid by those who break the by-laws (Minja and Machanya, 2010; Duguma et al., 2013). Different kind of Ngitili ownership exists, communal ownership, private ownership (individual ownership, household, and group ownership) and institutional ownership (school and religious organizations), (Kitalyi and Mlenge, 2004; Selemani et al., 2013).

The strong commitment by the local communities and the government attracted attention to the different organizations both within and outside (international, government and privates) that worked under the umbrella of traditional knowledge for land and forest restoration (Nyadzi et al., 2003). For instance, the Norwegian Agency for Development Cooperation (NORAD) became the primary donor of the program to promote Ngitili in Shinyanga from 1989 to 2004 (Duguma et al., 2019). The International Centre for Research in Agroforestry (ICRAF) has developed and implemented agroforestry practices complementary to Ngitili since 2002 (Duguma et al., 2013). The Tanzania Natural Forest Resources and Agroforestry Management Centre (NAFRAC), that takes responsibility of NORAD (UNDP, 2012), the Tanzania Traditional Energy Development and Environmental Organization (TaTEDO) that promotes energy-efficient technologies to reduce GHG emissions, from 2010 to 2013 (TaTEDO, 2009; TaTEDO, 2012). The Development Associates Ltd (DASS) conducts carbon monitoring and accounting in Ngitili systems. The programs resulted in outstanding successes. In 2004 more than 152 different trees, shrubs, and herbaceous were recorded in the region (Monela et al., 2005; Selemani et al., 2013). Plant species diversity values ranged from 2.0 to 3.8 concerning Shannon's index (Monela et al., 2005, Zahabu, 2008). A variable range of standing density and tree standing volume was from 922 to 6553 stem ha-1 and 5.1 to $48.9 \mathrm{~m}^{3} \mathrm{ha}^{-1}$, respectively (Monela et al., 2005; Otsyina et al., 2008).

Ceasing of the donors (NORAD) in 2004, most of the programs in Ngitili ceased as well (Chirwa, 2014). More ever, the entire situation about the current status of Ngitili in terms of conservation, plant diversity, and stocking potentials remains unreported. A few available pieces of works of literature focus on the performances of the pre-existing Ngitili and highlight the challenges. For instance, Chirwa (2014) reported that; conflict of interests, ineffective improvement strategies, and lack of recognition of the local institutions and their arrangements had converted the Ngitili into other land use. Similarly, Pye-Smith (2010) highlighted the lack of financial incentives and technical support provided by NORAD had accelerated the convention of Ngitili to other land use.

On the other hand, agroforestry, which mostly uses alien plant species due to their fast-growing ability, is not palatable to livestock and is characterized by high soil-water consumption (Cazzolla -Gatti et al., 
2014). Other noted factors include negative impacts of climate change, natural disturbance, high grazing pressure, bush fires, extensive wood collection, human population, and land competition for human settlement and agriculture (Pye-Smith, 2010; Chirwa, 2014). For instance, poor land preparation practices further threaten the sustainability of Ngitili conservation systems, the traditional 'slash and burn', and its typical shifting cultivation. Thus, most of the areas that were used to be Ngitili are no longer the same in the Shinyanga region. Unfortunately, the detailed information about these traditional practices (Ngitili) on forest management, sustainability, and conservation are highly neglected in the literature. Therefore, we carried out a detailed ecological study in Kishapu district of Shinyanga, northwest Tanzania in order: (i) to assess and document the current status of Ngitili, (ii) to determine the diversity of plant species, (iii) to evaluate the regeneration potential of plant species, and (iv) to quantify biomass stocking potential within Ngitili.

\section{Description of the study area}

The study was conducted in Kishapu district located in the northeast of the administrative region of Shinyanga (Figure 1). The district lies between $3^{\circ} 15^{\prime \prime}$ and $4^{\circ} 05^{\prime \prime}$ south of the equator and longitudes $31^{\circ}$ $30^{\prime \prime} \mathrm{E}$ and $34^{\circ} 15^{\prime \prime} \mathrm{E}$ east of the Greenwich meridian (URT, 2009). The district has a total area of 4,333 sq. $\mathrm{km}$. About $101 \mathrm{sq}$. km area is covered by forests, of which $47 \mathrm{sq} \mathrm{km}$ is occupied by community conserved forests (Ngitili). The district is characterized by a dry tropical climate with temperatures ranging from $22^{\circ} \mathrm{C}$ to $30^{\circ} \mathrm{C}$ and $15^{\circ} \mathrm{C}$ to $18.3^{\circ} \mathrm{C}$ for maximum and minimum. A semi-arid area receives $450 \mathrm{~mm}$ to $990 \mathrm{~mm}$ of rainfall per annum (NBS, 2012). Precipitation starts in late October/early November and ends in April/May, while the dry season begins in June and lasts in October. The rainfall amount and distribution patterns are neither even nor expectable (Bushesha and Katunzi, 2017); there is a decrease in rainfall, experiencing a gap between January and February.

The district is characterized by flat and gently undulating plains covered with low and sparse vegetation; soil varies with relief features (KDP, 2013). People in the district are engaging themselves in crops and livestock production. The principal food crops grown include maize, sorghum, bulrush millets, sweet potatoes, paddy, and pulses, while the cash crop is cotton (Katunzi et al., 2016). Livestock kept are cattle, shoats (sheep and goats), and poultry, but fishing is done during the rainy season (KDP, 2013).

\section{Forest inventory design and field layout}

Ten (10) community conserved forests, namely, Ikonda A, Mwamanota, Bubinza, Shagihilu, Busongo, Mihama, Bulima, Lyabujije, Ndoleleji, and Nyasamba found in the Kishapu district were selected for the purpose of study. For studying the current status and ecological attributes of Ngitili, ground-based forest inventory techniques (Brand et al., 1991) were employed. Permanent circular plots of $15 \mathrm{~m}$ radius (with inner sub-plots of 5 and $10 \mathrm{~m}$ ) were systematically laid along transects (Zahabu, 2008). The inter 


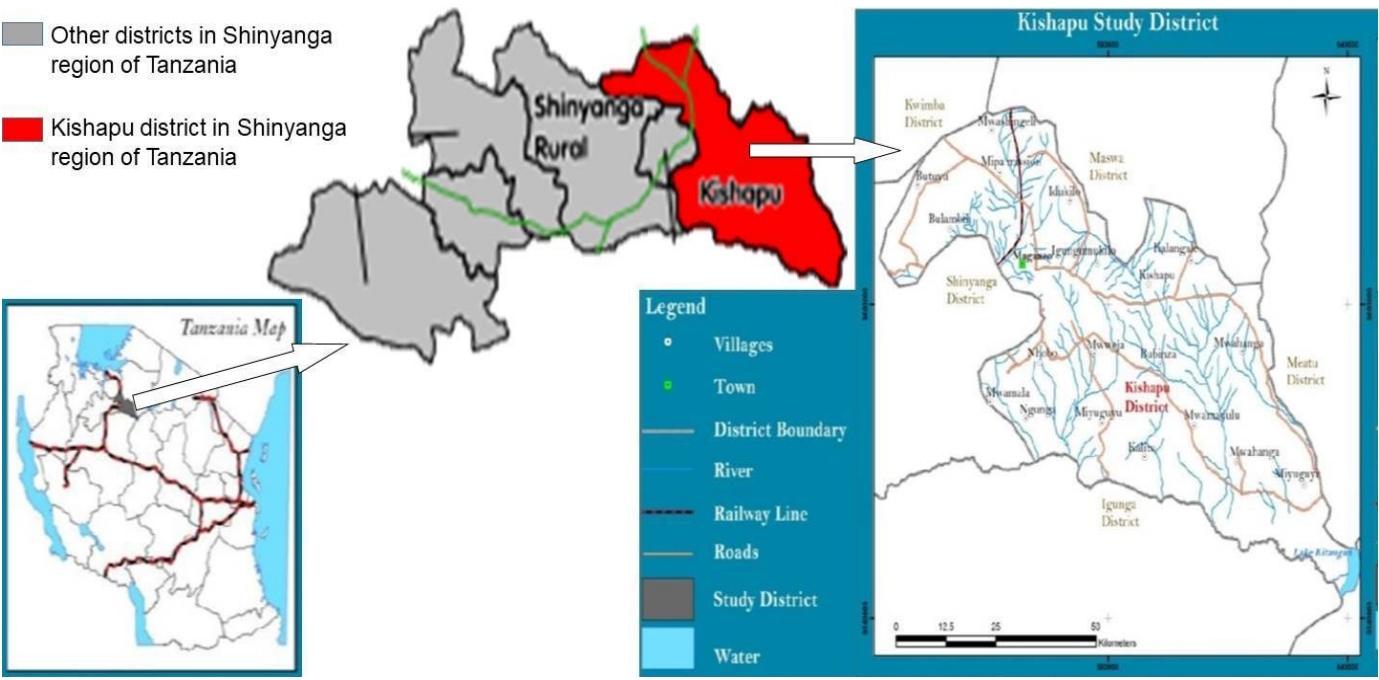

Figure 1. The Map of Shinyanga region to show studied community forests in Kishapu districts, northwest Tanzania.

plots and inter transects distances were maintained at 300 and $600 \mathrm{~m}$, in between, respectively. In each plot, plant phytosociological attributes (number of individual species, frequency, height and diameter at breast height) were recorded in the following manner:

- Within a $5 \mathrm{~m}$ radius: the frequencies of the individual herbaceous species were recorded. Seedling ( $\leq 20 \mathrm{~cm}$ height) and saplings ( $>20 \mathrm{~cm}$, but $<1 \mathrm{~m}$ height) were identified and recorded (Rubanza $e t$ al., 2006).

- Within a $10 \mathrm{~m}$ radius: all standing woody plant species with a diameter at breast height $(\mathrm{dbh})<5$ $\mathrm{cm}$ were identified and recorded as shrubs.

- Within a $15 \mathrm{~m}$ radius: all plants with $\mathrm{dbh} \geq 5 \mathrm{~cm}$ were identified and recorded as trees. In the forked trees, stems were numbered differently, and each stem were measured for dbh at $1.37 \mathrm{~m}$ and height. The measuring caliper was used to determine tree $\mathrm{dbh}(\mathrm{cm})$, while Suunto clinometer (PM-5/360 PC) was used to determine the tree heights (m) (Modified from Zahabu, 2008).

\section{Data collection}

\section{Status of community reserved forests}

A field survey was conducted to record the current status of community conserved forests (Ngitili). The disturbance score was calculated as per Veblen et al. (1992) and Gillespie et al. (2000). The disturbance was qualitatively classified into four classes versus the degree of anthropogenic activities (i.e., grazing pressure, wood fuel collection, agriculture, charcoal making, and fire outbreak). The anthropogenic activities were ranked as (1) for no evidence of anthropogenic activity; (2) for one or only two 
anthropogenic activities evidence; (3) for three shreds of evidence of anthropogenic activities; and (4) for more than three evidence of anthropogenic activities. The sum of all ranks provided the overall ranking of the anthropogenic disturbances (i.e., the low grade represents a low level of disturbance and vice versa). The disturbance index (DI) was calculated based on the number of individual cut stumps observed and recorded in the study site (Kanzaki and Yoda, 1986).

\section{Determination of floristic composition and ecological attributes}

The phytosociological study was carried out to recognize vegetation composition and plant species diversity using point sampling methods (Rubanza et al., 2006; Zahabu, 2008). The important plant community attributes such as frequency and abundance were quantitatively computed following Curtis and McIntosh (1950) and basal area following Phillips (1959). The relative frequencies, relative density, and relative dominance were calculated as per Curtis and McIntosh (Curtis and McIntosh, 1950), while the importance value index (IVI) of the individual plant species were determined by summing up the relative frequency, relative density, and relative dominance (Misra, 1989). Plant species diversity, richness, and evenness were computed using indices of diversity as per Shannon and Weaver (1949); Simpson (1949) and Pielou (1966), for Shannon's diversity index (H'), Simpson's dominance index $(C)$, and Evenness index ( $\left.J^{\prime}\right)$, respectively.

\section{Determination of plant regeneration potential}

The regeneration status of plant species was determined based on the population size of seedlings, saplings and adults (modified from (Khumbongmayum et al., 2006). Regeneration status was considered 'good' regeneration, if seedling > sapling > adults; 'fair' regeneration, if seedlings > or < saplings <adults; and 'poor' regeneration, if the species survives only in sapling stage, but no seedling (saplings may be <, > or = adults), (Khumbongmayum et al., 2006). While, if the species is recorded only in adult form, it was considered 'not regenerating', similar species with individuals only in seedlings or saplings without any adult was considered 'newly regenerating' species.

\section{Plant biomass stocking potential}

Herbaceous biomass was determined by the harvest method (Chambers, 1983), a destructive technique that involves clipping off the herbaceous species in a thrown quadrat (Rubanza et al., 2006). The clipped herbaceous species were immediately transferred to pre-weighed labeled bags, and instantly fresh weighted was recorded. The samples were taken into the laboratory for a forced-air oven at $60^{\circ} \mathrm{C}$ for 48 hours to obtain dry matter (DM). The dry matter contents were used to estimate the biomass production (Chambers, 1983) Eq 1.

(1) $\mathrm{B}\left(\mathrm{t} \mathrm{DM} \mathrm{ha}{ }^{-1}\right)=\frac{\mathrm{TDM}}{\mathrm{TQs}} \times \mathrm{QA}$

where; B- biomass, TDM- total dry matter contents, TQs- total quadrats, QA- quadrat area.

While, tree biomass stock was estimated by a non-destructive method (Chave et al., 2014; Chave et al., 2005). The method employs allometric equations, which considers measurable parameters like dbh, tree 
height, basal area, and wood density (Nath et al., 2019): Eqs. 2-4. Above-ground tree biomass (AGB) was computed as per (Vesa et al., 2010) Eq 2.

(1) AGB $\left(\mathrm{kg} \mathrm{tree}^{-1}\right)=\frac{\mathrm{g}^{*} \mathrm{~h}^{*} \delta}{1000}$

Where; g- basal area $\left(\mathrm{m}^{2}\right)$, h- height $(\mathrm{m}), \delta$ - wood density.

The BGB was estimated by multiplying the AGB to 0.26 (root to shoot ratio) as per Sheikh et al. (2011) and Suryawanshi et al. (2014): Eq 3.

(3) $\mathrm{BGB}\left(\mathrm{kg}\right.$ tree- $\left.{ }^{-1}\right)=\mathrm{AGB}^{*} 0.26$

The total tree biomass (TB) was determined as the sum of the AGB and BGB: Eq 4.

(4) $\mathrm{TB}\left(\mathrm{kg}\right.$ tree $\left.^{-1}\right)=\mathrm{ABG}+\mathrm{BGB}$

\section{Statistical analysis}

All data were normalized to fit parametric tests. Normality and homogeneity were verified using the Shapiro-Wilk and Levene tests, respectively. Descriptive statistics on plant species biomass stocking potential were analyzed statistically using analysis of variance (ANOVA). Fisher's Least Significant Difference Test (LSD) was carried out to test whether the differences between means were statistically significant at $\mathrm{p}<0.05$. All statistical analysis was performed using the SPSS Software package (ver. 20.0; SPSS, Chicago, IL) at a significance level of $\alpha=0.05$.

\section{Status of community conserved forests}

Different forms of fragmentation and the nature of community conserved forests have been observed in the present study. The results on the current status of community conserved forests of the Kishapu district are presented in Table 1. The present study surveyed to record the status in ten (10) community conserved forests in the district covering 6,112.98 ha. Nine conserved community forests contributed 4569.34 ha, while one forest recorded 1543.64 ha converted into other land use. Furthermore, out of the nine community conserved forests, four (2750.13 ha) are threatened (40 \%) and turning into a desertlike appearance (Figure 2), while the remaining (five) are highly disturbed (51\%).

The present study observed various ongoing human activities such as forest encroachment, agriculture, and other forms of human-induced disturbances such as burning, overgrazing, fuelwood extraction, which might be attributed to the degradation of the study sites. The factors such as conflict of interest and ineffective improvement strategies could have attributed as well. Other factors include introducing agroforestry, which mainly uses alien plant species due to their fast-growing nature, but in contrast, they require extra care, not palatable by livestock, and fail to adapt to harsh conditions. The reduced powers of the Dagashida (Group of elders) and the Sungusungu have been deliberated to the disappearance of most community forests. 


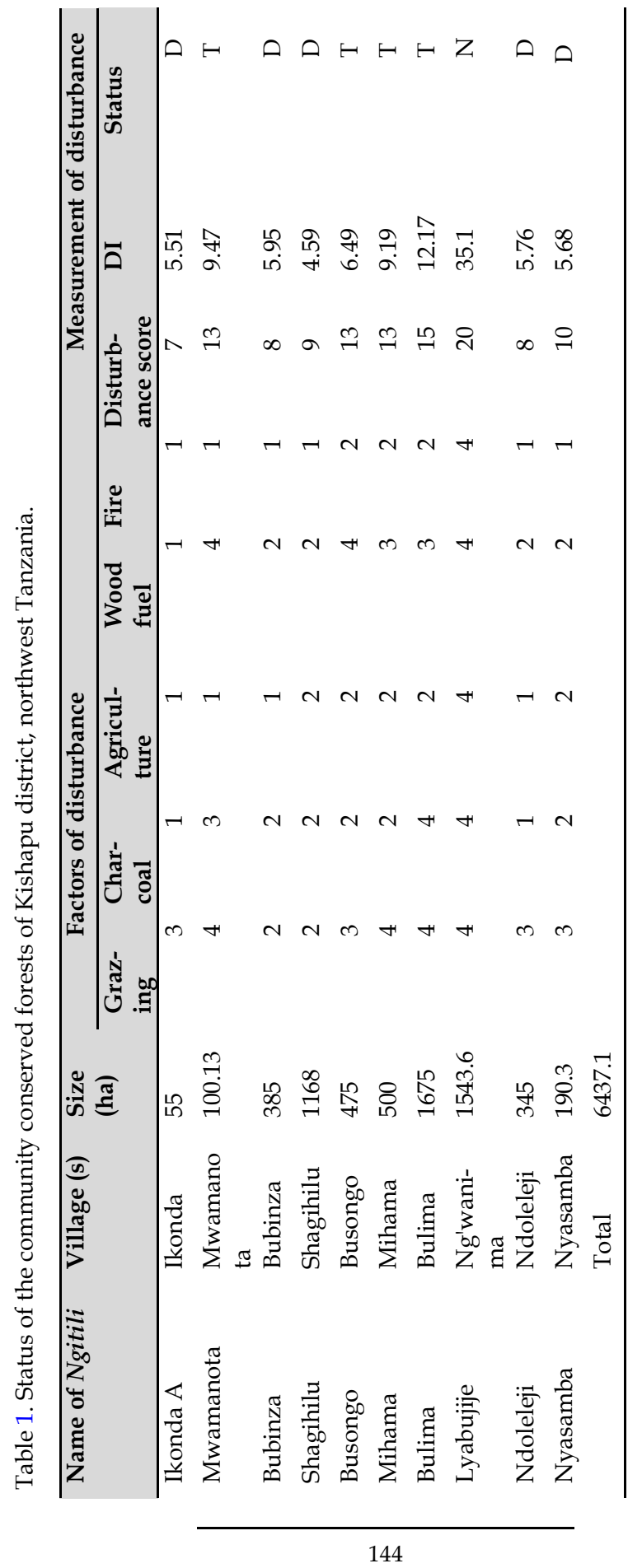



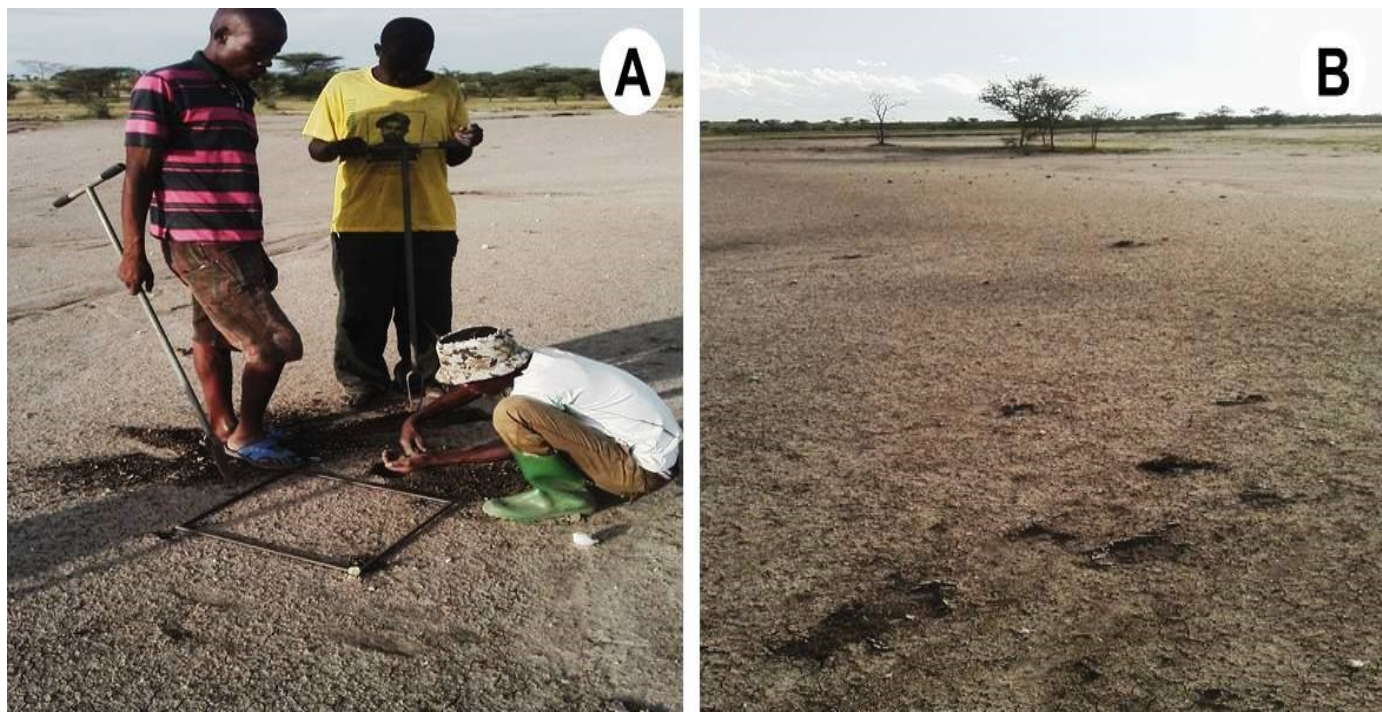

Figure 2. Threatened Ngitili showing bare ground with no grass covers turning into a desert-like appearance in Bubinza (A) and Shagihilu (B) community forests Kishapu, Tanzania.

The high level of civilization and the human population has resulted in a great conflict of interest, forcing people to opt for private forest conservation instead of community consideration. Minja and Machanya (2010) reported the exact reasons for declining community conserved forests in Tanzania. Cases related to misuse of forest-related resources are now handled by government police, who usually discourage the action that was taken by the local police Sungusungu. Therefore, the unrecognition of the Sungusungu in implementing the by-laws and protecting the communities against invaders has increased over exploitation of forest.

The demand for land for human settlement, agriculture, and livestock stocking was attributed significantly to high degradation in the region. Chirwa (2014) reported that much dependence on forest goods and services due to poverty has resulted in forest degradation. Similarly, the ceasing of supports from agents such as NORAD, charcoal making to sustain a livelihood, climate change, natural disturbance, grazing pressure, improper cultivation practices, deforestation, fires outbreak, and extensive fuelwood collection are some of the reasons for degradation in the region (Kamwenda, 2002; Rubanza et al., 2008; UNDP, 2012; Malunguja et al., 2020). On the other hand, Pye-Smith (2010) reported information on the human population and its threat to the community forest ecosystem. According to the report given by the World Agroforestry Centre (ICRAF) (Selemani et al., 2012), the growth of urban demand for charcoal and shift from previously practiced communal to private Ngitili has augmented the degradation of community conserved forests in the region. The reasons for such movement include low economic return, mainly due to unequal sharing of benefits, poor land security, poor grazing management, and unavoidable conflicts (Adams et al., 2003). Village government leaders make the 
decisions in communal forests on behalf of community members compared to private Ngitili (Machanya et al., 2003; Treue et al., 2014).

\section{Floristic composition and ecological attributes}

\section{Herbaceous composition}

38 herbaceous species (37 genera and 14 families) were identified in the studied Ngitili of Kishapu district in the Shinyanga region (Table 2). 20 species (19 genera and 3 families) were grasses, and 18 species (18 genera and 11 families) were forb and climber species. The dominant grass species include Aristida spp. (28.93\%), and Cynodon spp. (12.9\%). Other grass species with relatively high frequencies were Dactylectenium giganteum (6.1\%) and Eragrostis curvula (4.2\%), while dominant forb species were Monechma debile (4.6\%), Commelina spp., and Leucas spp. Grass species were more diverse (58\%) than forb species (42\%) in the study sites. The reported dominant herbaceous species in the current study denote that the species are native to the disturbed ecosystem. Grass species such as Aristida spp. and Cenchrus spp. are good indicators of disturbed aridity and semi-aridity zones (Monela et al., 2005; Otsyina et al., 2008; Selemani et al., 2012). However, the findings from the current work observed few species compared to Monela et al. (2005) in the surveyed Ngitili forests of Shinyanga. Heavy grazing pressure could have resulted in the disappearance of some native herbaceous species and leads to the domination of the recorded species due to their great tolerate and regeneration potential under harsh conditions. Rubanza et al. (2008) reported the decline of some edible herbage species "decreasers" as well as the emergence of less nutritious unpalatable species "increasers" that tend to dominate the place. The study observed that variation of soils is attributed to the presence of a particular dominant grass species. For instance, species such as Sorghum spp., Digitaria spp., and Rhynchelytrum spp. were found dominant in black clay soil locally known as Mbuga. Other grass species such as Aristida spp., Cenchrus spp., Heteropogon spp., Chloris spp., and Branchiaria spp. were localized in clay loam soil locally known as Ibushi. Water-loving species like Cynodon dactylon were found dominant in heavy clay vertisol soils (black cotton soil) characterized by high holding capacity and the associated waterlogging, which favors water-loving grass species. The dominant forb species include Cassia occidentalis, Convolvulus spp., Indigofera spp., Oxygonum sinuatum, and Sida spp., which indicates disturbed soil characteristics and could be associated with certain forms of land degradation. Pratt and Gwyne (1971) reported the same species in the semi-arid and disturbed landscapes of East Africa. High anthropogenic pressure and the absence of incentive from the government have contributed significantly to the present situation of degraded habitat.

\section{Tree species composition}

The present study recorded 28 tree species belonging to 17 genera and 13 families (Table 3). The dominant tree species recorded in the present study is from the genus Acacia. Another genus with relatively high dominance in the survey includes Dichrostachys, Lannea, and Balanites. The study recorded dominant tree and shrub species such as Acacia. nilotica, A. tortilis., A. drepanolobium., A. delile., 
Table 2. Herbaceous composition in community forests of Kishapu district, northwest Tanzania.

\begin{tabular}{|c|c|c|}
\hline Botanical name & Family & $\begin{array}{l}\text { Composition } \\
(\%)\end{array}$ \\
\hline \multicolumn{3}{|l|}{ Grass species } \\
\hline Aristida funiculata Trin. \& Rupr & Poaceae & 28.9 \\
\hline Branchiaria mutica (Forssk.) Stapf & Poaceae & 2.1 \\
\hline Cenchrus ciliaris L. & Poaceae & 3.2 \\
\hline Chloris barbata $\mathrm{Sw}$. & Poaceae & 1.5 \\
\hline Chloris gayana Kunth & Poaceae & 0.6 \\
\hline Cynodon dactylon (L.) Pers. & Poaceae & 12.9 \\
\hline Cyperus esculentus L. & Cyperaceae & 2.7 \\
\hline Dactyloctenium aegyptium (L.) Willd. & Poaceae & 6.1 \\
\hline Digitaria scalarum (Schweinf.) Chiov. & Poaceae & 0.8 \\
\hline Echinochloa colona (L.) Link & Poaceae & 0.1 \\
\hline Eragrostis curoula (Schrad.) Nees & Poaceae & 4.2 \\
\hline Heteropogon contortus (L.) P.Beauv & Poaceae & 0.4 \\
\hline Urochloa panicoides P.Beauv. & Poaceae & 0.2 \\
\hline Panicum trichocladum Hack. ex K. Schum. & Poaceae & 0.7 \\
\hline Rhynchelytrum repens (Willd.) C.E.Hubb. & Poaceae & 1.7 \\
\hline Rottboellia exaltata L. f. & Poaceae & 0.3 \\
\hline Setaria verticillata (L.) P.Beauv. & Poaceae & 1.4 \\
\hline Sorghum bicolor (L.) Moench & Poaceae & 0.2 \\
\hline Sporoborus spicatus Kunth & Poaceae & 1.8 \\
\hline Themada quadrivalvis (L.) Kuntze & Poaceae & 0.9 \\
\hline \multicolumn{3}{|l|}{ Forb and climber } \\
\hline Monechma debile (Forssk.) Nees & Acanthaceae & 4.6 \\
\hline Leucas martinicensis (Jacq.) R.Br. & Lamiaceae & 3.5 \\
\hline Commelina benghalensis L. & Commelinaceae & 3.3 \\
\hline Ipomoea batatas (L.) Lam. & Convolvulaceae & 2.8 \\
\hline Tribulus terrestris var. inermis & Zygophyllacea & 2.3 \\
\hline Amaranthus spinosus L. & Amaranthaceae & 2.2 \\
\hline Oxygonum sinuatum (Hochst. \& Steud.) & Polygonaceae & 2.2 \\
\hline Lycopersicon lycopersicum (L.) H. Karst. & Solanaceae & 1.8 \\
\hline Sonchus luxurians (R. E. Fr.) C. Jeffrey & Asteraceae & 1.5 \\
\hline Cucumis anguria L. & Cucurbitaceae & 1.1 \\
\hline Corchorus capsularis L. & Malvaceae & 0.8 \\
\hline Solanum incanum $\mathrm{L}$. & Solanaceae & 0.8 \\
\hline Sphaeranthus suaveolens (Forssk.) DC. & Asteraceae & 0.7 \\
\hline Abelmoschus esculentus (L.) Moench & Malvaceae & 0.5 \\
\hline Cleome gynandra L. & Cleomaceae & 0.5 \\
\hline Convolvulus prostratus Forssk. & Convolvulaceae & 0.4 \\
\hline Sida spinosa L. & Malvaceae & 0.2 \\
\hline Datura stramonium L. & Solanaceae & 0.1 \\
\hline
\end{tabular}

A. polyacantha, and A. Senegal. Other species such as Balanites spp. (desert plum) dominate the study sites. In order of importance value index (IVI), the dominant species under trees are; Acacia 
Table 3. Tree species composition community forests of Kishapu district, northwest Tanzania.

\begin{tabular}{|c|c|c|}
\hline Botanical name & Family & IVI \\
\hline Acacia angustissima (Mill.) Kuntze & Fabaceae & 6.77 \\
\hline Acacia bethamii Meisn. & Fabaceae & 6.09 \\
\hline Acacia concinna (Willd.) DC. & Fabaceae & 25.51 \\
\hline Acacia drepanolobium Harms ex Y.Sjöstedt & Fabaceae & 45.37 \\
\hline Acacia nilotica (L.) Del. & Fabaceae & 6.63 \\
\hline Acacia polyacantha Willd. & Fabaceae & 16.99 \\
\hline Acacia seyal Delile & Fabaceae & 15.53 \\
\hline Acacia senegal (L.) Willd. & Fabaceae & 33.2 \\
\hline Acacia tortilis (Forssk.) Hayne & Fabaceae & 6.63 \\
\hline Albizia amara (Roxb.) Boiv. & Fabaceae & 1.63 \\
\hline Azadirachta indica A. Juss. & Meliaceae & 5.53 \\
\hline Balanites aegyptiaca (L.) Delile & Zygophyllaceae & 42.96 \\
\hline Capparis tomentosa Lam. & Capparaceae & 0.57 \\
\hline Cassia abbreviata Oliv. & Caesalpiniaceae & 1.79 \\
\hline Colotropis procera (Aiton) W.T.Aiton & Apocynaceae, & 0.98 \\
\hline Combretum fraxgrans F.Hoffm. & Combretaceae & 1.84 \\
\hline Combretum obovatum F.Hoffm. & Combretaceae & 2.66 \\
\hline Dichrostachys cinerea Wight et Arn. & Fabaceae & 28.38 \\
\hline Diospyros fischeri Gürke & Ebenaceae & 2.57 \\
\hline Euphorbia ingens E.Mey. ex Boiss. & Euphorbiaceae & 1.43 \\
\hline Euphorbia tirucalli L. & Euphorbiaceae & 8.32 \\
\hline Grewia bicolor. Juss & Tiliaceae & 2.29 \\
\hline Lannea humilis (Oliv.) Engl. & Anacardiaceae & 33.57 \\
\hline Leucaena leucocephala (Lam.) de Wit & Fabaceae & 2.07 \\
\hline Ormocarpum kirkii S. Moore & Fabaceae & 3.86 \\
\hline Senna siamea (Lam.) de Wit & Fabaceae & 1.5 \\
\hline Senna singueana (Delile) Lock & Fabaceae & 1.43 \\
\hline Tamarindus indica L. & Fabaceae & 5.53 \\
\hline
\end{tabular}

drepanolobium (45.37), Balanites aegyptiaca (42.96), and Acacia tortilis (33.57), while Dichrostachys cinerea, recorded the highest domination for seedling and sapling.

\section{Species diversity}

Analysis of variance (ANOVA) indicated that there was no significant difference $(p>0.05)$ in plant species diversity. Diversity $\left(\mathrm{H}^{\prime}\right)$ in the present study ranges from 1.02 to 2.42 . Grass species recorded the highest diversity $\left(\mathrm{H}^{\prime}=2.34\right)$, while the lowest value was observed in tree species $\left(\mathrm{H}^{\prime}=2.05\right)$ (Table 4). The findings from the present study portray relatively low species diversity, characterizing a few species that dominate the study sites. The predominant species of the genus Acacia in the study area reflects an overgrazed and disturbed land, which should perhaps not be expected to demonstrate high 
species diversity. The present study observed poor vegetation recovery because of over-grazing, which does not offer sufficient vegetation to recover from one season to another.

Rubanza et al. (2008) pointed out that individuals of re-occurring species in Ngitili get grazed on their sapling stage; thereby, they never attain the adult stage to produce their next generation. Ngitili is only protected during the rainy season and grazed during the peak of the dry season when fodder for livestock is scarce. Thus, the low species diversity observed in the present study is associated with this grazing pressure. The findings from the present study show lower values of diversity $\left(\mathrm{H}^{\prime}\right)$ which contradicts the data reported in different districts of the region (Monela et al., 2005; Otsyina et al., 2008). Domesticated animals avoid consuming Acacia species due to the presence of thorns; thus, the species is less affected and dominates Ngitili.

Moreover, the species have a less valuable market for timber and charcoal production. According to Monela et al. (2005), excellent regeneration potential species like Dichrostachys cinerea and Omorcapum trichocarpum indicate degraded ecosystems. They have great adaptation to arid and semi-arid regions with low annual rainfall ( 400 to $800 \mathrm{~mm}$ ). These recorded tree and shrub species have similarly been reported in other parts of the region (Monela et al., 2005; Rubanza et al., 2006; Otsyina et al., 2008; Selemani et al., 2013). The high level of forest degradation and deforestation observed in the studied Ngitili might have been influenced by fewer plant species. Furthermore, Tefera et al. (2007) reported that plant species like Acacia might reflect an overgrazed land.

Table 4. Dominant species, diversity of plant species recorded in community reserved forests of Kishapu district, northwest Tanzania.

\begin{tabular}{|c|c|c|c|c|c|c|c|c|c|}
\hline $\begin{array}{l}\text { Plant } \\
\text { category }\end{array}$ & $\begin{array}{l}\text { Dominant plant species } \\
\text { based on calculated } \\
\text { composition }(\%) \text { and IVI }\end{array}$ & SR & $\mathbf{H}^{\prime}$ & C & $\mathbf{J}^{\prime}$ & EF & WI & NF & NG \\
\hline Grasses & $\begin{array}{l}\text { Aristida spp. }(28.93 \%), \\
\text { Cynodon spp. }(12.9 \%), \\
\text { Dactyloctenium giganteum } \\
(6.1 \%), \text { Eragrostis curvula } \\
(4.2 \%) \text { and Cenchrus ciliaris } \\
(3.20 \%) .\end{array}$ & 20 & $\begin{array}{l}1.02- \\
2.34\end{array}$ & $\begin{array}{l}0.08- \\
0.11\end{array}$ & 0.91 & 9 & 0.06 & 3 & 19 \\
\hline $\begin{array}{l}\text { Forbs and } \\
\text { climbers }\end{array}$ & $\begin{array}{l}\text { Monechma debile }(4.6 \%) \text {, } \\
\text { Leucas martinicensis }(3.5 \%) \text {, } \\
\text { Commelina benghalensis (3.3 } \\
\%) \text {, Ipomoea batatas ( } 2.8 \%) \\
\text { and Tribulus terrestris } \\
(2.3 \%) .\end{array}$ & 18 & $\begin{array}{l}1.13- \\
2.42\end{array}$ & $\begin{array}{l}0.09- \\
0.04\end{array}$ & 0.9 & 13 & 0.09 & 11 & 18 \\
\hline Trees & $\begin{array}{l}\text { Acacia drepanolobium } \\
\text { (45.37), Balanites aegyptiaca } \\
(42.96), \text { Lannea humilis } \\
\text { (33.57), Acacia tortilis (33.20) } \\
\text { and Dichrostachys cinerea } \\
\text { (28.38). }\end{array}$ & 28 & $\begin{array}{l}1.90- \\
2.05\end{array}$ & $\begin{array}{l}0.07- \\
0.12\end{array}$ & 0.93 & 6 & 0.06 & 13 & 17 \\
\hline
\end{tabular}

Note: SR -species richness; H' -Shannon-Wiener diversity index; C -Simpson's index (1/D); J' -Pielou's index of evenness; EF -effective number of species; WI -Whitford index; NF -Number of the family; NG -Number of the genus. 


\section{Regeneration potential status}

The present study observed a high percentage (51.85\%) of plant species exhibits a "Not regeneration" condition followed by "Poor regeneration" (25.4\%), "Fair regeneration" (20.7 \%), and "Good regeneration" recorded the lowest value $(2.1 \%)$. The present study doesn't observe any newly regenerated species (Table 5). The absence of new regeneration in the study area indicates that the prevailing environmental conditions are either unsuitable for new species to colonize or there is high pressure of grazing and other anthropogenic activities that fail to establish new upcoming species. The present study's findings portray a destructive regeneration potential, an indicator of threat to the native species leading to local extinction. Illegal utilization of species by communities to sustain their livelihood for charcoal making, medicinal, unstable climate, and edaphic variability attributes to poor regeneration of individual species. Both anthropogenic and natural phenomena affect regeneration potential (Iqbal et al., 2012). Scarcity of grazing land and lower ecological carrying capacity resulted from poor adaptability of some species to degraded ecosystem contributed to the degradation of plant species among Ngitili in Shinyanga (Selemani et al., 2012). Therefore, the sustainability of the Ngitili is threatened by extensive grazing and overexploitation of species by communities to meet their daily livelihood requirements.

\section{Tree biomass stocking}

The total tree stocking is $12.04 \mathrm{tB} \mathrm{ha}^{-1}$ and results of tree biomass stocking potential are presented in Table 7. Plant species that have relatively high stocking potential are; Acacia polyacantha $\left(2.11 \mathrm{tB} \mathrm{ha}^{-1}\right)$, Acacia tortilis (1.46 tB ha-1) and Balanites aegyptiaca (1.33 tB ha-1). The community forests recorded relatively low biomass stocking potential compared to other reports in the region (Zahabu, 2008). The observed low stocking potential signifies the high degree of disturbance, particularly illegal tree cutting for charcoal making. This is evidenced by the presence of charcoal kilns and a large number of cut stumps. Other reasons could be explained by the absence of large-sized tree individuals with sufficient girth and height, which are essential parameters for assessing tree stocking. The present study observed that most large-sized trees are cut for charcoal making to sustain livelihood and family economy. The low biomass in community reserved forests of the region signifies poor carbon dioxide $\left(\mathrm{CO}_{2}\right)$ contribution offset through carbon sequestration for enhanced climate change mitigation. The present

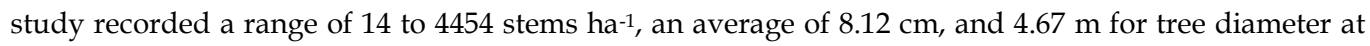
breast height (dbh), and heights (h), respectively. The findings of this study concur with Selemani et al. (2013), who reported an average of $578 \pm 70$ tree stems ha-1 and a height of $3.24 \mathrm{~m}$ in Shinyanga rural of Meatu districts. However, the findings from the present study are lower than the data reported by Monela et al. (2005) of 1964 to 6553 stems ha-1, and 6.7 to $27.2 \mathrm{~cm}$, for tree stem density and diameter at breast height (dbh), respectively. The estimated values are similarly contrasted to Otsyina et al. (2008) of 1053 to 1360 stems ha-1. The high level of forest degradation and deforestation observed during the present study is directly related to the low biomass stocking. The growing urban demand for charcoal has accelerated the degradation of Ngitli. Furthermore, a great shift from community-owned to private Ngitili in the region is among the main reasons for the degradation and low biomass stocking. 
Table 5. Tree species composition community forests of Kishapu district, northwest Tanzania.

\begin{tabular}{|c|c|c|c|c|c|}
\hline \multirow[t]{2}{*}{ Botanical name } & \multicolumn{4}{|c|}{ Number of individual adult plants } & \multirow{2}{*}{$\begin{array}{l}\text { Regener- } \\
\text { ation } \\
\text { status }\end{array}$} \\
\hline & Shrubs & Trees & Seedlings & Saplings & \\
\hline Acacia nilotica (L.) Del. & 41 & 124 & 38 & 67 & FR \\
\hline $\begin{array}{l}\text { Acacia drepanolobium Harms ex } \\
\text { Y.Sjöstedt }\end{array}$ & 135 & 315 & 326 & 432 & GR \\
\hline $\begin{array}{l}\text { Acacia angustissima (Mill.) } \\
\text { Kuntze }\end{array}$ & 2 & 2 & 1 & 0 & NR \\
\hline Acacia polyacantha Willd. & 15 & 15 & 3 & 11 & NR \\
\hline Acacia senegal (L.) Willd. & 3 & 15 & 4 & 6 & NR \\
\hline Acacia bethamii Meisn & 5 & 6 & 0 & 2 & PR \\
\hline Acacia tortilis (Forssk.) Hayne & 28 & 102 & 9 & 16 & FR \\
\hline Azadirachta indica A. Juss. & 1 & 2 & 1 & 2 & NR \\
\hline Balanites aegyptiaca (L.) Delile & 40 & 142 & 21 & 18 & FR \\
\hline Capparis tomentosa Lam. & 44 & 3 & 0 & 3 & NR \\
\hline Cassia abbreviata Oliv. & 1 & 2 & 0 & 0 & NR \\
\hline $\begin{array}{l}\text { Colotropis procera (Aiton) } \\
\text { W.T.Aiton }\end{array}$ & 7 & 1 & 13 & 24 & FR \\
\hline Combretum obovatum F.Hoffm & 5 & 1 & 0 & 0 & NR \\
\hline $\begin{array}{l}\text { Dichrostachys cinerea Wight et } \\
\text { Arn. }\end{array}$ & 95 & 101 & 87 & 65 & GR \\
\hline Euphorbia tirucalli L. & 1 & 2 & 0 & 0 & NR \\
\hline $\begin{array}{l}\text { Euphorbia ingens E.Mey. ex } \\
\text { Boiss. }\end{array}$ & 12 & 1 & 7 & 9 & FR \\
\hline Grewia bicolor. Juss & 7 & 1 & 2 & 6 & NR \\
\hline $\begin{array}{l}\text { Leucaena leucocephala (Lam.) de } \\
\text { Wit }\end{array}$ & 19 & 6 & 13 & 21 & FR \\
\hline Senna siamea (Lam.) de Wit & 1 & 1 & 17 & 5 & FR \\
\hline Senna singueana (Delile) Lock & 6 & 1 & 0 & 0 & NR \\
\hline Tamarindus indica L. & 1 & 2 & 0 & 6 & PR \\
\hline Ormocarpum kirkii S. Moore & 21 & 7 & 6 & 19 & FR \\
\hline Acacia concinna (Willd.) DC & 81 & 151 & 21 & 43 & GR \\
\hline Combretum fraxgrans F.Hoffm. & 14 & 1 & 0 & 0 & NR \\
\hline Diospyros fischeri Gürke & 5 & 6 & 1 & 3 & NR \\
\hline Albizia amara (Roxb.) Boiv. & 10 & 1 & 13 & 6 & FR \\
\hline Lannea humilis (Oliv.) Engl. & 125 & 2 & 37 & 123 & GD \\
\hline
\end{tabular}

\section{Conclusion}

From the present study, anthropogenic activities (i.e., cultivation, deforestation, overutilization, overgrazing etc.) attributed to the observed threatened status in community reserved forests (Ngitili) of Kishapu district, northwest Tanzania. Lack of incentives regarding awareness, monetary and technical 


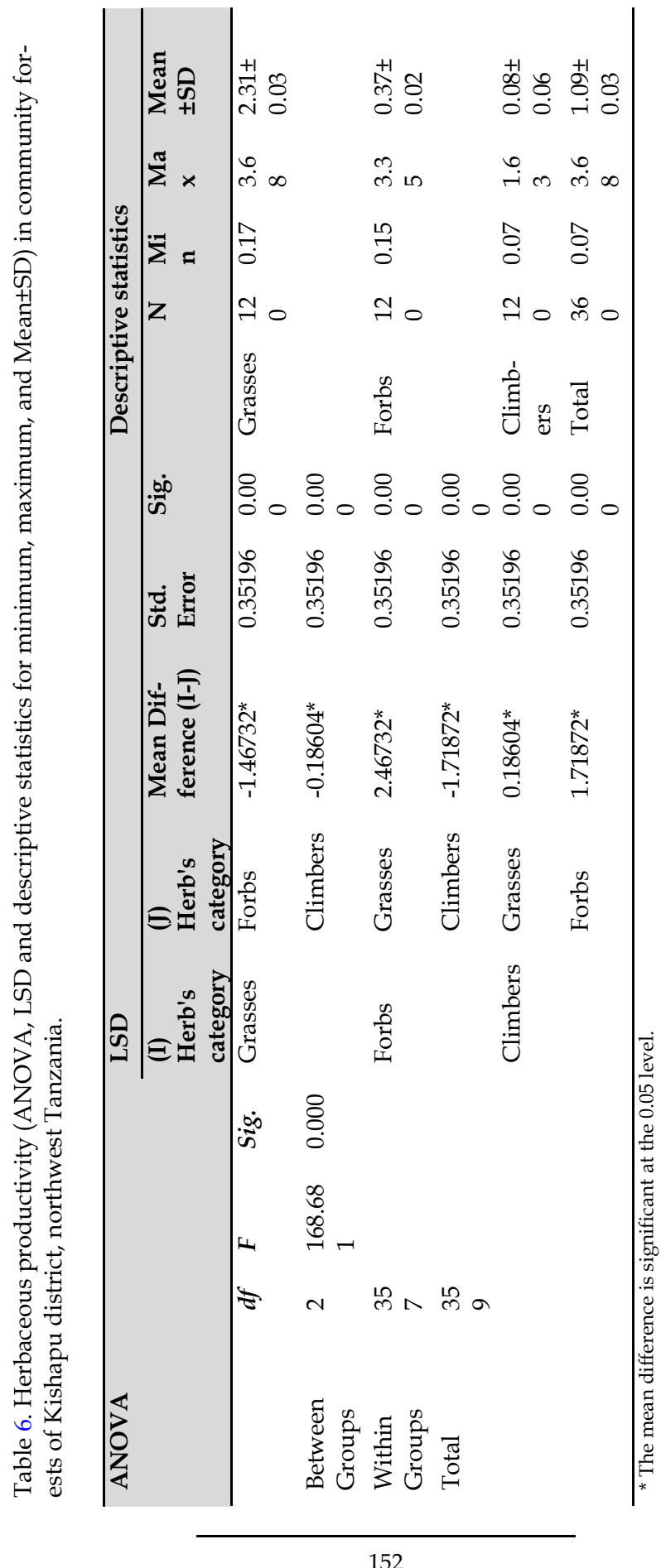


Table 7. Tree-wise biomass stocking potential in community forests of Kishapu district, northwest Tanzania.

\begin{tabular}{|c|c|c|c|c|c|c|c|}
\hline Botanical name & $\begin{array}{l}\text { Stems } \\
\text { ha-1 }^{-1}\end{array}$ & $\begin{array}{l}\text { Height } \\
\text { (m) }\end{array}$ & $\begin{array}{l}\mathrm{dbh} \\
\text { (cm) }\end{array}$ & $\begin{array}{l}\text { Volume } \\
\left(\mathrm{m}^{3} \text { ha }^{-1}\right)\end{array}$ & $\begin{array}{l}\text { AGB } \\
\text { t ha-1 }\end{array}$ & $\begin{array}{l}\text { BGB } \\
\text { t ha-1 }\end{array}$ & $\begin{array}{l}\text { TB } \\
\text { t ha-1 }\end{array}$ \\
\hline Acacia nilotica (L.) Del. & 1753 & 6.8 & 18.5 & 1.231 & 0.616 & 0.154 & 0.770 \\
\hline $\begin{array}{l}\text { Acacia drepanolobium } \\
\text { Harms ex Y.S. }\end{array}$ & 4454 & 4.4 & 5.5 & 0.143 & 0.071 & 0.018 & 0.089 \\
\hline $\begin{array}{l}\text { Acacia angustissima (Mill.) } \\
\text { Kuntze }\end{array}$ & 28 & 5.6 & 10.9 & 0.897 & 0.448 & 0.112 & 0.560 \\
\hline Acacia polyacantha Willd. & 212 & 7.4 & 16.8 & 3.381 & 1.691 & 0.423 & 2.113 \\
\hline Acacia senegal (L.) Willd. & 212 & 4.3 & 9.5 & 0.489 & 0.244 & 0.061 & 0.306 \\
\hline Acacia bethamii Meisn & 84 & 5.9 & 11.3 & 0.951 & 0.475 & 0.119 & 0.594 \\
\hline $\begin{array}{l}\text { Acacia tortilis (Forssk.) } \\
\text { Hayne }\end{array}$ & 1442 & 7.1 & 15.8 & 2.331 & 1.166 & 0.291 & 1.457 \\
\hline Azadirachta indica A. Juss. & 28 & 4.6 & 6.7 & 0.737 & 0.368 & 0.092 & 0.460 \\
\hline $\begin{array}{l}\text { Balanites aegyptiaca (L.) } \\
\text { Delile }\end{array}$ & 2007 & 6.1 & 8.8 & 2.122 & 1.061 & 0.265 & 1.326 \\
\hline Capparis tomentosa Lam. & 42 & 2.7 & 4.7 & 0.129 & 0.065 & 0.016 & 0.081 \\
\hline Cassia abbreviata Oliv. & 28 & 3.7 & 6.4 & 0.171 & 0.085 & 0.021 & 0.107 \\
\hline $\begin{array}{l}\text { Colotropis procera (Aiton) } \\
\text { W.T.Aiton }\end{array}$ & 14 & 1.6 & 3.6 & 0.038 & 0.019 & 0.005 & 0.024 \\
\hline $\begin{array}{l}\text { Combretum obovatum } \\
\text { F.Hoffm }\end{array}$ & 14 & 3.9 & 4.2 & 0.299 & 0.150 & 0.037 & 0.187 \\
\hline $\begin{array}{l}\text { Dichrostachys cinerea } \\
\text { Wight et Arn. }\end{array}$ & 1428 & 3.6 & 5.2 & 0.254 & 0.127 & 0.032 & 0.159 \\
\hline Euphorbia tirucalli L. & 28 & 5.3 & 7.9 & 1.317 & 0.658 & 0.165 & 0.823 \\
\hline $\begin{array}{l}\text { Euphorbia ingens E.Mey. } \\
\text { ex Boiss. }\end{array}$ & 14 & 4.2 & 6.2 & 0.159 & 0.079 & 0.020 & 0.099 \\
\hline Grewia bicolor. Juss & 14 & 3.6 & 3.4 & 0.235 & 0.117 & 0.029 & 0.147 \\
\hline $\begin{array}{l}\text { Leucaena leucocephala } \\
\text { (Lam.) de Wit }\end{array}$ & 84 & 5.3 & 5.3 & 0.152 & 0.076 & 0.019 & 0.095 \\
\hline $\begin{array}{l}\text { Senna siamea (Lam.) de } \\
\text { Wit }\end{array}$ & 14 & 5.7 & 8.7 & 0.228 & 0.114 & 0.029 & 0.143 \\
\hline $\begin{array}{l}\text { Senna singueana (Delile) } \\
\text { Lock }\end{array}$ & 14 & 3.1 & 5.8 & 0.118 & 0.059 & 0.015 & 0.074 \\
\hline Tamarindus indica L. & 28 & 6.5 & 13.6 & 1.041 & 0.520 & 0.130 & 0.650 \\
\hline $\begin{array}{l}\text { Ormocarpum kirkii S. } \\
\text { Moore }\end{array}$ & 98 & 2.8 & 6.5 & 0.234 & 0.117 & 0.029 & 0.146 \\
\hline $\begin{array}{l}\text { Acacia concinna (Willd.) } \\
\text { DC }\end{array}$ & 2135 & 6.4 & 8.8 & 0.673 & 0.337 & 0.084 & 0.421 \\
\hline $\begin{array}{l}\text { Combretum fraxgrans } \\
\text { F.Hoffm. }\end{array}$ & 14 & 5.4 & 5.8 & 0.275 & 0.138 & 0.034 & 0.172 \\
\hline Diospyros fischeri Gürke & 84 & 3.2 & 6 & 0.148 & 0.074 & 0.018 & 0.092 \\
\hline $\begin{array}{l}\text { Albizia amara (Roxb.) } \\
\text { Boiv. }\end{array}$ & 14 & 2.6 & 3.2 & 1.374 & 0.687 & 0.172 & 0.859 \\
\hline $\begin{array}{l}\text { Lannea humilis (Oliv.) } \\
\text { Engl. }\end{array}$ & 28 & 4.3 & 10.2 & 0.133 & 0.066 & 0.017 & 0.083 \\
\hline Total & 14323 & 126.10 & 219.30 & 19.26 & 9.63 & 2.41 & 12.04 \\
\hline
\end{tabular}


support, and unequal sharing of resources from communal-owned Ngitili have played a significant role in low plant species diversity among Ngitili. Similarly, the Elders' Council reduced authority power, locally known as "Dagashida," and the unrecognition of the local guard (police) known as Sungusungu in implementing the by-laws and protecting the communities against invaders has increased forest overexploitation. Low levels of environmental education, poverty, and more demand for land expansion for agriculture due to increasing population have accelerated deforestation and land degradation. On the other hand, the high level of forest degradation and deforestation observed in the present study is directly related to the low plant species diversity, primary biomass production, and stocking. Therefore, effective and appropriate management interventions such as environmental education to raise awareness are of utmost importance. Re-establishment and strengthening community participation in conservation and management practices for sustainable harvest and resource utilization are required with practical action to enhance forests and land sustainability.

\section{Acknowledgments}

The authors would sincerely thank the field crew members, Sandu Peter, Mhija Budeba, and Mbwiga Emmanuel. We are grateful to Laboratory Technician Ms. Rosy Njawala from the Department of Natural Resources Management and Agroforestry Centre (NAFRAC), Shinyanga Region. Thanks to Tanzania Forestry Research Institute (TAFORI), Shinyanga Region, for their sincere and friendly cooperation. We offer our thanks to Kishapu District Council for permitting us to conduct the study among community forests within their administrative boundary.

\section{References}

Adams, W.M., Brockington, D., Dyson, J., and Vira, B. (2003). Managing Tragedies: Understanding Conflict over CommonPool Resources. Science, 302(5652): 1915-1916. https://doi.org/10.1126/ science.1087771

Akida, A. and Blomley, R. (2006). Trends in Forest Ownership, Forest Resources Tenure, and Institutional Arrangements: Are They Contributing to Better Forest Management and Poverty Reduction? Case Study from Tanzania, pp. 26.

Barrow, E. (2016). Shinyanga Forest: Retrofitting Resilience to the Shinyanga Forest Landscape Restoration Case Study. In Gland IUCN, Switzerland, in collaboration with The Rockefeller Foundation Copyright, pp. 16. https:// doi.org/10.2305/iucn.ch.2016.11.en

Barrow, E and Mlenge, W. (2003). Trees as key to pastoralist risk management in semi-arid landscapes in Shinyanga, Tanzania, and Turkana, Kenya. In The International Conference on Rural Livelihoods, Forests and Biodiversity, pp. 18.

Barrow, E. (2014). Shinyanga Forest Retrofitting Resilience to the Shinyanga Forest Landscape Restoration Case Study. International Union for Conservation of Nature, pp. 48.

Barrow, E., Timmer, D., White, S. and Maginnis, S. (2002). Forest Landscape Restoration: Building Assets for People and Nature-Experience from East Africa communities, pp. 1-13.

Brand, D.G., Leckie, D.G. and Cloney, E.E. (1991). Forest regeneration surveys: design, data collection, and analysis. Forestry Chronicle, 67(6): 649-657.

Buckingham, K. and Hanson, C. (2015). The Restoration Diagnostic. Case Example: Shinyanga Region, Tanzania, pp. 36.

Burgess, N.D., Bahane, B., Clairs, T., Danielsen, F., Dalsgaard, S. et al. (2010). Getting ready for REDD+ in Tanzania: A case 
study of progress and challenges. Oryx, 44(3): 339-351. https://doi.org/10.1017/S0030605310000554

Bushesha, M. and Katunzi, W. (2017). An Assessment of Autonomous Adaptation Practices to Climate Change in Kishapu District Tanzania. Environment, 1(1): 25-42. https://doi.org/10.31058/j.envi.2017.11003

Cazzolla-Gatti, R., Castaldi, S., Lindsell, J.A., Coomes, D.A., Marchetti, M., Maesano, M., Di Paola, A., Paparella, F. and Valentini, R. (2014). The impact of selective logging and clearcutting on forest structure, tree diversity, and above-ground biomass of African tropical forests. Ecological Research, 30(1):119-132.

Chambers, J.C. (1983). Methods for Vegetation Sampling and Analysis on Revegetated Mined Lands (Intermountain Forest and Range Experiment Station (ed.)). Forests and forestry.

Chave, J., Andalo, C., Brown, S., Cairns, M. A., Chambers, J. Q., Eamus, D. et al. (2005). Tree allometry and improved estimation of carbon stocks and balance in tropical forests. Oecologia, 145(1): 87-99. https://doi.org/10.1007/s00442-005-0100-x

Chave, J, Réjou-Méchain, M., Búrquez, A., Chidumayo, E., Colgan, M.S., Delitti, W.B.C., Duque, A., Eid, T., Fearnside, P.M., Goodman, R.C., Henry, M., Martínez-Yrízar, A., Mugasha, W.A., Muller-Landau, H.C., Mencuccini, M., Nelson, B.W., Ngomanda, A., Nogueira, E.M., Ortiz-Malavassi, E. and Vieilledent, G. (2014). Improved allometric models to estimate the aboveground biomass of tropical trees. Global Change Biology, 20(10): 3177-3190. https://doi.org/10.1111/gcb.12629

Chirwa, P.W. (2014). Restoration practices in degraded landscapes of Eastern Africa. In African Forest Forum, 2 (11):1-26.

Curtis, J. and McIntosh, R. (1950). The Interrelations of Certain Analytic and Synthetic Phytosociological Characters. Ecology 31(3): 434-455.

Dery, B., Otsyina, R. and Ng'atigwa, L. (1999). Indigenous knowledge of medicinal trees and setting priorities for their domestication in Shinyanga Region, Tanzania. In (D. BB, R. Otsyina, \& N. C (eds.)). International Centre for Research in Agroforestry, pp. 20-33.

Duguma, L.A., Minang, P.A., Kimaro, A.A., Otsyina, R. and Mpanda, M. (2013). Climate-smart landscapes: Integrating mitigation, adaptation, and development in Shinyanga region Tanzania, Partnership for the Tropical Forest Margins Nairobi, pp. 40.

Duguma, L., Minang, P., Kimaro, A., Otsyina, R. and Mpanda, M. (2019). Blending old and new agroforestry to integrate development, climate change mitigation, and adaptation in Tanzania. In: van Noordwijk M, ed. Sustainable development through trees on farms: agroforestry in its fifth decade. Bogor, Indonesia: World. In Sustainable development through trees on farms: agroforestry in its fifth decade. Bogor, Indonesia: World Agroforestry (ICRAF) Southeast Asia Regional Program, pp. 137-149.

Gillespie, T.W., Grijalva, A. and Farris, C.N. (2000). Diversity, composition, and structure of tropical dry forests in Central America. Plant Ecology, 147(1): 37-47.

Iqbal, K., Pala, N., Bhat, J. and Negi, A.K. (2012). Regeneration status of trees around Khoh river in Garhwal Himalaya. Indian Journal of Forestry, 35(4), 471-476

Jama, B. and Zeila, A. (2005). Agroforestry in the drylands of eastern Africa: A call for action. ICRAF Working Paper No 1, pp. 1-38.

Kanzaki, M. and Yoda, K. (1986). Regeneration in subalpine coniferous forests: Mortality and the pattern of death of canopy trees. Bot Meg Tokyo, 99: 37-52.

Kamwenda, G.J. (2002). Ngitili agrosilvipastoral systems in the United Republic of Tanzania. Unasylva, 53(211): 46-50.

Katunzi, A. Bushesha, T. and Mwakalila, I. (2016). Examining Rainfall and Temperature Pattern Change over Time: A Case of Kishapu District, Shinyanga Region in Tanzania. Climate Change, 2(8): 557-572.

KDP. (2013). Kishapu District Development Director, Catalogy; Shinyanga-Tanzania. Kishapu District Commissioner's Office, pp. 140.

Kitalyi A. and Mlenge W. (2004). An Indigenous Natural Resource Management System in Shinyanga, Tanzania. ALIN Eastern Africa, pp. 1-30.

Khumbongmayum, D.A., Khan, M.L. and Tripathi, R.S. (2006). Biodiversity conservation in sacred groves of Manipur, northeast India: Population structure and regeneration status of woody species. Biodiversity and Conservation, 15(8): $2439-2456$.

Machanya, J.M., Minja, E.M., Mwesiga, P.K and Msangi, H.B.A. (2003). Report. The blooming degraded land HASHI experience, 1986-2003. Ministry of Natural Resources the United States of Tanzania, pp. 37. 
Malcolm, D. (1953). Sukumaland: An African People and Their Country: Study of Land Use in Tanganyika. OUP, London. pp. 123.

Malunguja, G.K., Rubanza, C.K.D. and Devi, A. (2020). An assessment of the current status and regeneration potential of the traditional conserved forests ( Ngitili ) in Kishapu district, Tanzania. The Journal of the Society for Tropical, 7(2): 336-356.

Minja, E.T.W, and Machanya, J. (2010). A study on institutional set-up and governance of Ngitili in the REDD pilot project areas of the Shinyanga region, pp. 1-16.

Misra, K. (1989). Manual of Plant Ecology (3rd ed.). Oxford and IBH Publishing Co. Pvt. Ltd.

Monela, G., Chamshama, S., Mwaipopo, R. and Gamassa, D. (2005). A study on the social, economic, and environmental impacts of forest landscape restoration in Shinyanga Region, Tanzania, pp. 219.

Nath, A.J., Tiwari, B.K., Sileshi, G.W., Sahoo, U.K., Brahma, B., Deb, S., Devi, N. B., Das, A. K., Reang, D., Chaturvedi, S.S., Tripathi, O.P., Das, D.J. and Gupta, A. (2019). Allometric models for estimation of forest biomass in North East India. Forests, 10(103). https:// doi.org/10.3390/f10020103

National Bureau of Statistics (NBS) (2012). A Census Report on Population Distribution of 2012. Population Census Administration Unit Report, Dar Salaam, Tanzania. https://www.nbs.go.tz/index.php/en/

Nyadzi, GI., Otsyina, RM., Banzi, FM., Bakengesa, SS., Gama, BM., Mbwambo, L. and Asenga, D. (2003). Rotational woodlot technology in northwestern Tanzania: Tree species and crop performance. Agroforestry Systems, 59: 253-263.

Osei, A.K., Kimaro, A.A., Peak, D., Gillespie, A.W. and Van Rees, K.C.J. (2018). Soil carbon stocks in planted woodlots and Ngitili systems in Shinyanga, Tanzania. Agroforestry Systems, 92(2):251-262. https://doi.org/10.1007/s10457-016-0028-7

Otsyina, R.M., Essai, I. and Asenga, D. (1992). Traditional Grassland and Fodder Management Systems in Tanzania and Potential for Improvement, 1379:1-2.

Otsyina, R., Rubanza, C.D.K., and Zahabu, E. (2008). Contribution of tree planting and conservation activities to carbon offsets in Shinyanga, Final report submitted to Royal Norwegian embassy, pp. 1-19.

Pielou, E.C. (1966). Species-diversity and pattern-diversity in the study of ecological succession. Journal of Theoretical Biology, 10(2): 370-383.

Philips, E.A. (1959). Methods of vegetation study. Henry Holt and Co.Inc; New York. p. 318

Pratt, D.J. and Gwyne, M. (1971) Rangelands Management and Ecology in East Africa. Publishing Company, Huntington. New York. pp. 310.

Rubanza, C.D.K., Shem, M.N., Ichinohe, T. and Fujihara, T. (2006). Biomass production and nutritive potential of conserved forages in silvopastoral traditional fodder banks (Ngitili) of meatu district of Tanzania. Asian-Australasian Journal of Animal Sciences, 19(7): 978-983. https://doi.org/10.5713/ajas.2006.978

Shannon, C.E. and Weaver, W. (1949). The Mathematical Theory of Communication. Urbana, IL The University of Illinois Press Urbana, pp. 1-117.

Selemani, I.S., Eik, L.O., Holand, Ø., Ådnøy, T., Mtengeti, E. and Mushi, D. (2012). The role of indigenous knowledge and perceptions of pastoral communities on traditional grazing management in northwestern Tanzania. African Journal of Agricultural Research, 7(40): 5537-5547. https://doi.org/10.5897/AJAR12.1468

Sheikh, M.A., Kumar, M., Bussman, R.W. and Todaria, N.P. (2011). Forest carbon stocks and fluxes in physiographic zones of India. Carbon Balance and Management, 6:1-10. https:/ / doi.org/10.1186/1750-0680-6-15

Simpson, E.H. (1949). Measurement of diversity. In Nature, 163(4148): 688. https://doi.org/10.1038/163688a0

Suryawanshi, M.N., PateL, A.R., Kale, T.S. and Patil, P.R. (2014). Carbon sequestration potential of tree species in the environment of North Maharashtra University Campus, Jalgaon, India. Bioscience Discovery, 5(2): 175-179.

TaTEDO (2009). Community REDD+ mechanism for sustainable natural resources management in semi-arid areas: Case of Ngitilis in Shinyanga Region. REDD+ Project proposal submitted to NORAD, pp. 138.

TaTEDO (2012). Pilot Project on Community-Based REDD+ Mechanisms for Sustainable Forest Management in Semi-Arid Areas (Case of Ngitilis in Shinyanga Region). Project Final Report. Dar Es Salaam: TaTEDO and Development Associates Ltd, pp. 260.

Tefera, S. Snyman, HA. and Smit, G. (2007). Rangeland dynamics in southern Ethiopia: (3). Assessment of rangeland condition in relation to land-use and distance from water in semi-arid Borana rangelands. Journal of Environmental Manage- 
ment, 85(2): 453-460.

Treue, T., Ngaga, Y.M., Meilby, H., Lund, J.F., Kajembe, G., Iddi, S., Blomley, T., Theilade, I., Chamshama, S.A.O., Skeie, K., Njana, M.A., Ngowi, S.E., Isango, J.A.K. and Burgess, N.D. (2014). Does participatory forest management promote sustainable forest utilization in Tanzania? International Forestry Review, 16(1): 23-38.

UNDP (2012). Shinyanga Soil Conservation Programme (HASHI), Tanzania. Equator Initiative Case Study Series. New York, NY.

URT (2002). Forest Act, Ministry of Natural Resources and Tourism; Government of Tanzania Printer: Dar es salaam, Tanzania.

URT (2006). Third National Report on the Implementation of the Convention on Biological Diversity: Vice President's Office Division of Environment.

URT (2009). Kishapu District Profile, District Development Director, Shinyanga-Tanzania.

Veblen, T.T., Kitzberger, T. and Lara, A. (1992). Disturbance and forest dynamics along a transect from Andean rain forest to Patagonian shrubland. Journal of Vegetation Science, 3(4): 507-520. https://doi.org/10.2307/3235807

Vesa, L., Malimbwi, R., Tomppo, E. and Zahabu, E. (2010). A national forestry resources monitoring and assessment of Tanzania. http:/ /41.73.194.142:8080/xmlui/handle/123456789/1287

Zahabu, E. (2008). Sinks and Sources a Strategy to Involve Forest Communities in Tanzania in Global Climate Policy; Ph.D. thesis, University of Twente, Netherlands. https://doi.org/10.3990/1.9789036527736.

Zahabu, E., Eid, T., Kajembe, G., Mbwambo, L., Mongo, C., Sangeda, A., Malimbwi, R., Katani, J., Kashaigili, J. and Luoga, E. (2009). Forestland tenure systems in Tanzania: an overview of policy changes in relation to forest management. INA Fagrapport, 1- 14 .

$* * * * *$

Cite this chapter as: Malunguja, G.K., Chowdhury, R., Mokhets'engoane, S., Diliban, N.P., Zeleke, T.Y., Sharma, P.S., Devi, A. and Rubanza, C.D.K. (2021). Indigenous knowledge in forest conservation, species diversity and stocking potential: A historical perspectives of northwest Tanzania. In: Biological Diversity: Current Status and Conservation Policies, Volume 1, Eds. Kumar., V., Kumar, S., Kamboj, N., Payum, T., Kumar, P. and Kumari, S. pp. 136-157, https://doi.org/10.26832/ aesa2021-bdcp-09 